\title{
UGT1A Locus
}

National Cancer Institute

\section{Source}

National Cancer Institute. UGT 1A Locus. NCI Thesaurus. Code C127927.

Human UGT 1A gene locus is located in the vicinity of $2 \mathrm{q} 37$ and is approximately $188 \mathrm{~kb}$ in length. This locus includes nine protein-encoding genes and four pseudogenes. The protein-encoding genes are involved in glucuronidation of toxins, drugs and xenobiotics. 